\title{
Efficiency of design offers on realization of ecological reconstruction in construction
}

\author{
Veronika Luchkina* \\ Moscow State University of Civil Engineering, Yaroslavskoe shosse, 26, Moscow, 129337, Russia
}

\begin{abstract}
In view of new construction market and National Project requirements, there is a growing demand in the construction environmental specialists in this field. The article analyses the results of scientific and practical developments in ecological restoration which are being implemented to a degree in the municipal economy and construction. This field of activity has been poorly researched in the studies yet, but it has been already used in construction of unique buildings and constructions, and ecological construction projects. The author has compared the assessment criteria of investment projects for standard (S) and energyefficient houses (E). The life cycle analysis results provide for assessing the energy-efficient house and confirm that the rising cost at the construction stage is repaid for multiple times at the operation stage. The research has shown that the $2 \%$ investment rise for construction of the energy-efficient house would increase the return on investment by 10 times during the building life cycle. Such return is achieved due to energy cost saving. It can be noted that to construct an energy-efficient house as an option of ecological restoration design proposal implementation, various technologies which can both increase and reduce construction cost are used. The increased energy efficiency has a powerful economic and environmental effect and is of interest not only for the enterprises and creditors, but also for the public as to the positive results of the energy efficient project implementation, the increased economic and environmental safety of the country are the additional advantages of the energy efficient building construction that increase the attractiveness of such projects for the bank investment lending.
\end{abstract}

\section{Introduction}

Increased density of the urbanized complexes and increased toxicity level in cities - these are the factors requiring literate environmental specialists. New market requirements for construction quality of buildings and structures are relevant and the field-specific construction environmental specialists are in greater demand. Having searched in the Internet, no one will be surprised to find the already formed profession like a construction environmental specialist. The construction environmental specialist is engaged in planning

\footnotetext{
* Corresponding author: luchkinavv@ mail.ru
} 
of buildings and structures considering the use of environment-friendly construction materials and conducts the environmental monitoring of construction.

Both domestic and foreign researchers are engaged in formation of ecologically integrated education. In the frameworks of the subject "Project Management" where the energy efficient construction can be considered, the survey of a team of students of the Moscow State University of Civil Engineering was conducted (100 students were interviewed). The level of interest in the environmental education system of the interviewed students found out the following:

- $60 \%$ are not interested in the environmental knowledges;

- $30 \%$ would like to increase the environmental culture level and attend the environmental workshops;

- $10 \%$ took part in various environmental events and projects [1].

The implementation of the environmental education system in construction is related to the development of the following areas:

1 Environmental safety in construction: harmonization of state and international standards;

2 Energy efficiency and environment enhancement;

3 Ecoplanning of buildings, structures and territories [2].

\section{Materials and Methods}

Having analysed the list of state standards in construction and nature protection, it can be concluded that a wide range of such standards has been developed. Such standards were reviewed in the sections which names were compliant with the names of the main environmental components, for example, "Nature Protection. Atmosphere", "Nature Protection. Hydrosphere", and so on.

In view of the environmental friendliness of constructions, there is a separate section 13 "Environmental Protection. Human Protection against Environmental Exposure. Safety". The previously developed Building Codes and Regulations (SNiP) are being currently updated. This means the gradual transition to status of rulebooks being binding. The dynamical progress in construction called harmonization of national and foreign standards should be also taken into account. If to distinguish such field of construction as engineering, the European Committee for Standardization has developed the construction engineering standards called Eurocodes. The Eurocodes are integrated into nine groups:

The EU Directives play important role in bringing the standards of the European countries into line with each other. The Directives contain the detailed description of requirements the executors to be governed by, as well as the procedures to be implemented. For example, EN 15603 "Energy performance of buildings. Overall energy use and definitions of energy ratings" containing the methods to be followed when determining the energy ratings of buildings. There are also other documents on the methods of energy ratings of buildings and energy consumption certification in the frameworks of the directives. The environmental safety in construction in Russia should be used in practice in view of harmonization of national and foreign standards. The "green construction" standards can be given as examples of organizations developed similar to the technical documents of other countries.

The ecological restoration covers a complex of the undertaken measures to ensure environmental safety, recovery and rehabilitation of people and nature, life environment created and being created, including settlements, arrangement of territories and sustainable development of cities based on integration of the ground-breaking global progress and high technology in the conditions of sustainable development [3]. The achievement of these 
goals is connected with the mastery and ability to create innovative technologies in the frame the ecological restoration.

The Academy of International Ecological Restoration has structured a tree of objectives for ecological restoration as a part of the development of project proposals for the ecological restoration implementation by the specialists of the Moscow State Academy of Public Utilities and Construction. The research of ecological restoration contains a range of software and project complexes, projects and programs. The main areas cover a whole range of monitoring the people's activities [4]:

- Ecological restoration of landscapes;

- Ecological restoration of the living environment of the settlements;

- Ecological restoration of the regions.

\section{Discussion}

Let us analyse some project proposals in the framework of the environmental arrangement of buildings and structures, made and tested by leading scientific institutes, scientists and engineers of Russia. It can be concluded that the activity of ecological restoration is underway and covers various areas of construction. The national project is designed to provide Russian citizens with affordable and comfortable "environmentally friendly" housing. We believe that the direction of the environmental safety of constructed residential facilities is promising for the researchers. Already formed architectural and technological solutions can be used for the green design and construction of the building[5]:

- Intelligent systems inside and outside the houses.

- Passive solar heating and cooling systems.

- Low speed wind turbines.

- Heat pumps in heating, ventilation, air conditioning systems in order to utilize thermal energy.

- Additional daylight sources for the building.

- Building greening systems.

- Separate sewage system.

- Solar panels on the roof of buildings.

- Solar collectors on the roof for hot water.

- Heat energy storage in the basement.

- External or internal wall insulation with effective thermal insulation.

- Winter gardens located on the south side of the buildings.

- Arrangement of new glazed loggias with the use of special measures to attenuate outdoor noise.

The following facilities are been created in order to implement the above directions:

- Political and cultural centres.

- Business centres.

- Human and nature ecological restoration clubs.

- International exchange of projects and programs of national academies and corporations.

These projects include "Ecological restoration of the Ostankino park - Resort in the city", International Project "Seliger", complex "Eurasian house of ecological restoration", etc. The analysis of project proposals shows that in the future the leading directions of ecological restoration will include [6]:

- Creation of systems of ecological, intellectual and energy-efficient buildings and structures;

- Passive houses with ecological landscaping;

- Environmentally-friendly clothing based on innovative technology; 
- Environmentally-comfortable and energy-efficient transport;

- Ecological diagnostics, ecological risks, ecological insurance;

- Ecological settlements;

- Environmental dismantling of buildings and the use of recycled products in the framework of renovation programs.

The terms of reference for designing an sustainable environment contain a specific list of sections. When creating the engineering systems, own inventions and patents of authors of ecological restoration projects are often used. For example, the terms of reference for the design of a sustainable environment in closed rooms, contains the following list $[7,8]$ :

1 Project proposal objective;

2 Equipment complex purpose;

3 List of controlled parameters and characteristics of the apartment;

4 Finishing, decorative, health-improving materials;

5 Required improvements of engineering systems;

6 Requirements for the installation of power supply lines;

7 Requirements for room acoustics;

8 Central dust removal system;

9 Floor heating system;

10. System of footwear and outerwear pollutant removal.

\section{Conclusions}

The investment activity and the payback period of such projects is also important in the framework of the development of environmental restoration projects. The basis of the investment project examination is an economic assessment based on the well-known UNIDO (United Nations Industrial Development Organization) methodology.

An investment project aimed at implementing the ecological restoration of a building has advantages over a project for the construction of a standard building .

The selection of investment projects can occur on the basis of qualitative and quantitative analysis with an appropriate system of indicators. A number of the most appropriate indicators were selected and analysed. The criteria for evaluating the investment projects for financing standard - S - and environmental restoration were compared, using the example of building an energy-efficient house - E (Table 1).

Table 1. Comparison of criteria for evaluating investment projects

\begin{tabular}{|l|l|l|l|l|}
\hline No. & Criteria & S & E & Comments \\
\hline 1 & Quantitative & & & \\
\hline 2 & $\begin{array}{l}\text { Investment payback } \\
\text { period }\end{array}$ & & +++ & High costs \\
\hline 3 & Return on investment & & & $\begin{array}{l}\text { Flat for the bank, determined by the } \\
\text { terms of the contract }\end{array}$ \\
\hline 4 & Internal rate of return & & $\begin{array}{l}\text { Flat for the bank, with the same interest } \\
\text { rate }\end{array}$ \\
\hline 5 & Bruno criterion & & ++ & $\begin{array}{l}\text { Flat for the bank, equal to the interest } \\
\text { rate on the loan }\end{array}$ \\
\hline 6 & Risk indicators & $\begin{array}{l}\text { The country will have the opportunity to } \\
\text { reduce the volume of imports of energy } \\
\text { carriers, however the construction of an } \\
\text { energy efficient house requires additional } \\
\text { materials. }\end{array}$ \\
\hline
\end{tabular}




\begin{tabular}{|c|c|c|c|c|}
\hline & & & & investment in the project \\
\hline & Qualitative & & & \\
\hline 7 & Commercial criteria & & ++ & $\begin{array}{l}\text { More profitable in terms of the high } \\
\text { value of the asset, larger profitability of } \\
\text { the project for the owner }\end{array}$ \\
\hline 8 & Institutional criteria & & ++ & $\begin{array}{l}\text { The sector undergoes growth and has } \\
\text { significant prospects. }\end{array}$ \\
\hline 9 & Environmental criteria & & +++ & $\begin{array}{l}\text { Significant positive environmental effect } \\
\text { due to reduced energy consumption }\end{array}$ \\
\hline 10 & Social criteria & & ++ & Benefits for the society \\
\hline 11 & Uncertainty & + & & $\begin{array}{l}\text { There is uncertainty about the future cost } \\
\text { of energy, which can adversely affect the } \\
\text { payback of the project, and threatens } \\
\text { with non-payment }\end{array}$ \\
\hline 12 & Confidence equivalent & & + & $\begin{array}{l}\text { The studies show a higher cost of selling } \\
\text { and renting energy-efficient houses. }\end{array}$ \\
\hline & & & $\begin{array}{l}\text { Where "+" } \\
\text { is a minor } \\
\text { advantage; } \\
\text { "++" is a } \\
\text { partial } \\
\text { advantage; } \\
\text { "+++" is a } \\
\text { significant } \\
\text { advantage }\end{array}$ & \\
\hline
\end{tabular}

It is believed that while being operated, the energy-efficient buildings today can provide certain environmental and social preferences, and economic benefits should be obtained in the future, thus the economic efficiency of the buildings is assessed throughout their life cycle: "Construction - operation - disposal". For this reason, the life cycle cost (LCC) method is used for the economic rationale of energy efficient construction.

LCC - Expenditure / Release model modification is used as a method for estimating the building's value. The LCC includes the following expenses: initial purchase or construction costs; costs associated with the use of energy, water and other utilities; costs for operation and maintenance $(\mathrm{O} \& \mathrm{M})$, costs for the replacement of building systems; residual value or disposal costs; non-monetary benefits; taxes and loan payments.

There are various data on such economic indicators as the increase in the cost of construction of an energy-efficient building compared to the construction of a standard house and the relative indicators of savings in further operation.

The life cycle analysis results provide for assessing the energy-efficient house and confirm that the rising cost at the construction stage is repaid for multiple times at the operation stage. The research has shown that the $2 \%$ investment rise for construction of the energy-efficient house would increase the return on investment by 10 times during the building life cycle. Such return is achieved due to energy cost saving.

The cost of constructing a passive house is about 30\% higher than is required for the conventional construction. The estimated cost of an energy-efficient house exceeds the cost of constructing a standard one by an average of 5-8\%, and in some cases even by $15 \%$.

According to other data, the combination of supporting structures and climate support systems made it possible to define a new class of building systems called thermo active accumulative building systems, TAABS. Practical research, construction and operation provided the following results: TAABS - reduces the design time by $35-40 \%$, cost - by $10-$ $15 \%$, and operation - by $50-70 \%$ with a tendency to increase the last digits. 
It has been established that somewhat higher initial costs for certified energy efficient buildings are compensated several times by the level of occupancy of premises, higher cost, high rents, higher selling prices and low operating costs.

Thus, Energy Star-certified commercial construction will be by $3 \%$ more expensive than standard one. The increase in the effective rent for certified energy-efficient buildings is also significant - about $7 \%$. There was an increase in the sale price by $16 \%$ for energyefficient houses for a significant number of commercial properties as compared to standard ones.

The calculations show an increase in the market value of $1.1 \%$ and a $1.2 \%$ increase in the average premium of more than sixteen percent $(16 \%)$ for each ten-percent $(10 \%)$ decrease in energy consumption. On average, one dollar decrease in energy loss yields eighteen dollars thirty-two cents $(\$ 18.32)$ of increased market value and one dollar in energy consumption savings yields twenty dollars seventy-three cents $(\$ 20.73)$ increase in the value of the building.

In conclusion, it can be noted that for the construction of an energy-efficient house, as an option of the implementation of the ecological restoration project proposal, various technologies are used that can either increase, or decrease the construction cost. The increased energy efficiency has a powerful economic and environmental effect and is of interest not only for the enterprises and creditors, but also for the public as to the positive results of the energy efficient project implementation, the increased economic and environmental safety of the country are the additional advantages of the energy efficient building construction that increase the attractiveness of such projects for the bank investment lending. Thus, such factors as forecasts of rising energy prices, the accumulation and the international use of significant amounts of financial resources to finance energy efficient projects, the positive environmental and economic effect of improving energy-efficiency on the other hand prove the promise of investing in the projects aimed at construction of energy-efficient buildings (ecological restoration projects).

\section{Reference}

1. Luchkina V.V. Optimization of the project of energy efficient construction and the analysis of the market of energy efficient technologies at design of buildings//System technologies, 28, 5-12 (2018)

2. Fokov R.I. Ecological reconstruction and improvement of the urbanized environment: Monograph (ACB, 2012)

3. ISO 10006:2003 «Quality management systems - Guidelines for quality management in projects (IDT)» ( New Delhi: BIS, 2003)

4. V.V. Luchkina, IOP Conf. Series: Earth and Environmental Science, 90, 1-6, (2017)

5. R.R. Kazaryan, MATEC Web of Conferences, 193, 01009, (2018)

6. R.R. Kazaryan, MATEC Web of Conferences, 193, 04023, (2018)

7. S.A. Sinenko, MATEC Web of Conferences, 21, 09007 (2017)

8. B.V. Zhadanovsky, S.A. Sinenko, Computing in Civil and Building Engineering Proceedings International Conference, 1, 137-142, (2014) 